\title{
ARTICLE
}

\section{Molecular identification of Auxis spp. larvae (Pisces: Scombridae) from the Gulf of California: Solving morphological identification limits}

Identificación molecular de larvas de Auxis spp. (Pisces: Scombridae) del Golfo de California: Resolviendo límites en la identificación morfológica

\section{María J. Ochoa-Muñoz ${ }^{1,3}$, Noé Díaz-Viloriaa,", Laura Sánchez-Velasco, Sylvia P.A. Jiménez-Rosenberg ${ }^{1}$ and Ricardo Pérez-Enríquez ${ }^{2}$}

${ }^{1}$ Instituto Politécnico Nacional, Centro Interdisciplinario de Ciencias Marinas (IPN-CICIMAR), Departamento de Plancton y Ecología Marina, Av. Instituto Politécnico Nacional s/n Col. Playa Palo de Santa Rita, La Paz, B.C.S., 23096, México. *Corresponding author: ndviloria@hotmail.com

${ }^{2}$ Centro de Investigaciones Biológicas del Noroeste, S.C., Instituto Politécnico Nacional 195, Colonia Playa Palo de Santa Rita Sur, La Paz, B.C.S., 23096, México

${ }^{3}$ Fundación CIDEMAR - Ciencia y Divulgación en Ecología Marina y Dulceacuícola, Villanelo 180 oficina 1405, Viña del Mar, 2571496, Chile

Resumen.- Las larvas del género Auxis son abundantes en el Golfo de California durante verano, sin embargo su identificación a nivel de especie mediante métodos morfológicos es un desafío. El objetivo de este estudio fue identificar larvas de $A$. thazard y A. rochei por primera vez a través de marcadores moleculares, usando secuencias de COI de ADNmt y buscar características morfológicas distintivas entre especies, principalmente en los patrones de pigmentación. Se obtuvieron larvas mediante arrastres de zooplancton en tres cruceros oceanográficos en el sur del Golfo de California y aguas adyacentes. Se confirmó genéticamente la presencia de larvas de $A$. thazard y de $A$. rochei. Las secuencias de 7 larvas mostraron divergencias genéticas menores al $1 \%$ al ser comparadas con secuencias de adultos de $A$. thazard, mientras que 15 larvas mostraron divergencias genéticas menores al $2 \%$ al ser comparadas con secuencias de adultos de $A$. rochei. Las divergencias genéticas entre ambas especies de Auxis fueron mayores al $2 \%$. Estos resultados sugieren el desove de ambas especies en el Golfo de California. Por otro lado, los patrones de pigmentación y características morfométricas en todos los estadios larvarios no permitieron la identificación segura entre especies. Por lo tanto, se recomienda el uso de la identificación molecular mediante COI para identificar las larvas de Auxis a nivel de especie, así como en otras larvas de peces marinos recolectados en otras regiones del mundo, que tienen problemas de identificación.

Palabras clave: Identificación molecular, COI, larvas, Auxis rochei, Auxis thazard

\begin{abstract}
The larvae of the Auxis genus are abundant in the Gulf of California during summer; however, their identification to the species level by morphological methods is a challenge. The goal of this study was to identify $A$. thazard and $A$. rochei larvae for first time, through molecular markers using COI sequences of mtDNA, and look for distinctive morphological characteristics between species, mainly in pigmentation patterns. Larvae were obtained by zooplankton tows in 3 oceanographic cruises in the southern Gulf of California and adjacent waters. The presence of $A$. thazard and A. rochei larvae was genetically confirmed. The sequences of 7 larvae showed genetic divergences lower than $1 \%$ when were compared to sequences of $A$. thazard adults, while 15 larvae showed genetic divergences lower than $2 \%$ when where compared to sequences of $A$. rochei adults. Genetic divergences between both Auxis species were higher than $2 \%$. These results suggest the spawning of both species in the Gulf of California. On the other hand, pigmentation patterns and morphometric characteristics, in all larval stages, did not permit the secure differentiation between species. Thus, the use of molecular identification by $\mathrm{COI}$ is recommended to identify Auxis larvae to the species level, as well as in other marine fish larvae collected in other regions of the world, that have identification troubles.
\end{abstract}

Key words: Molecular identification, COI, larvae, Auxis rochei, Auxis thazard 


\section{INTRODUCTION}

Scombridae, which includes tunas, bonitos, and mackerels, is one of the pelagic fish families highly important in sport and commercial fisheries around the world (Richards 2006). Within this family is the genus Auxis Cuvier, 1829, which is composed of small tunas (40 $\mathrm{cm}$ of fork length approx.) of 2 species: Frigate tuna Auxis thazard Dresslar \& Fesler, 1889 and Bullet tuna A. rochei Risso, 1810. Their distribution has been registered from temperate, subtropical, and tropical waters along the equatorial belt, inhabiting near-shore waters during the reproductive season, after which they migrate to the open ocean to feed and continue with their life cycle (Majkowski 2007). The larvae of the Auxis genus have been reported as one of the most abundant taxa in the Gulf of California during summer (Sánchez-Velasco et al. 2013, ApangoFigueroa et al. 2015).

The identification of Auxis species in adult specimens is largely based on some particular characteristics: teeth of the jaws are thin and conical, corselet well developed, first and second dorsal fins are widely separated, the position of the tip of the pectoral fin in reference to the naked dorsal area and the number of gill rakers (Collette 2001, Joshi et al. 2012). However, as such morphological characteristics are not developed at larval stages, it is not possible to differentiate between Auxis species at those stages. In general, larvae strongly differ in morphology from the adults, and identifying them to the species level remains challenging (Ko et al. 2013; Leis 2015; Collet et al. 2017). Traditionally, larval identification has always used morphological characters, such as body shape, pigmentation, meristic count and measurements (Azmir et al. 2017). However, identification based on morphology is not always effective when many pre-bend larval species share meristic and morphometric characters making their recognition very complex or even ambiguous (Pappalardo et al. 2015). In addition, larval fish are so delicate that they are often badly damaged during collection and fixation that caused loss of pigmentation pattern which greatly help during identification process (Valdez-Moreno et al. 2010).

Studies about larvae distribution in the Mediterranean Sea and the Pacific Ocean, refer imprecisely to both species as Auxis spp., despite the presence of adults of both species in their respective areas (Ayala 1998, Rebollar-Prudente 2000, García et al. 2002, AvendañoIbarra et al. 2013). The available bibliography of fish larvae taxonomy in the north-eastern Pacific (Moser 1996) does not show clear differences in morphometric, meristic, and pigmentation patterns that support differentiation between A. thazard and A. rochei larvae. Even though a previous morphological analysis differentiated between two Auxis larval types as type I and type II, it was not clear how the type I and type II were identified as $A$. rochei and $A$. thazard, respectively, based only in their ossification degrees (Rebollar-Prudente 2000). However, the traditional taxonomy of larvae has implemented molecular techniques that permit species identification (Ko et al. 2013).

In the last decade, genetic techniques have been applied to clarify the presence of one or more scombrid species of fish in different regions of the world. Chow et al. (2003) used morphology and 3 molecular markers of mitochondrial DNA (mtDNA): restriction fragment length polymorphism (RFLP), cytochrome $b$ (cyt $b$ ), and a flanking region between ATPase and cytochrome oxidase subunit III, to distinguish larvae and juveniles of different tuna fish in the tropical and subtropical West Pacific. Species of $A$. thazard and $A$. rochei were genetically identified; however, morphologic characters alone did not permit their classification in specimens smaller than $6 \mathrm{~mm}$ of length. Paine et al. $(2007,2008)$, using sequences of cytochrome oxidase $c$, subunit I (COI) of mtDNA, showed genetic differentiation between $A$. thazard and $A$. rochei in the western Atlantic Ocean and Hawaii. Robertson et $a l$. (2007), using cytochrome $b$ (cyt $b$ ) sequences, differentiated 9 species of Scombridae, with similar morphologies in postlarval and juvenile stages in northwestern Australia. Mudumala et al. (2011), using COI sequences, showed low intra-specific (0.002-0.003) and high inter-specific (0.028) divergences between $A$. thazard and $A$. rochei. Kumar et al. (2013), with COI, found evolutionary differences between $A$. thazard and $A$. rochei, concluding that $A$. rochei is the more ancestral species. Puncher et al. (2015), found misidentification of tuna larvae following morphology-based methods for the Mediterranean Sea and concluded that genetic barcoding is a legitimate technique that can support species identification and play a crucial role in fisheries management efforts.

The objective of this study was to test the current taxonomic hypothesis of morphological differentiation of Auxis spp. larvae, coupled with the COI based identification system. Once identified, was looked for morphological characteristics that could possibly help in larval identification to the species level. 


\section{Materials AND Methods}

\section{SAMPLING}

Larvae of Auxis spp. were collected during 3 oceanographic cruises at the entrance and southern Gulf of California (Fig. 1). The first (GOLCA1107) was carried out from the southern Gulf of California to the Midriff Archipelago region $\left(25^{\circ}-29^{\circ} \mathrm{N}\right.$ and $\left.109^{\circ}-113^{\circ} \mathrm{W}\right)$, aboard the R/V El Puma, from 26th July to 6th August 2011. The second (GOLCA1204) was performed from the southern Gulf of California to Cabo Corrientes $\left(21^{\circ}-25^{\circ} \mathrm{N}\right.$ and $106^{\circ}$ $110^{\circ} \mathrm{W}$ ), aboard the R/V Francisco de Ulloa, from 26th April to 4th May 2012. The third was done to the west of San Lorenzo channel in Bahía de La Paz $\left(24.3^{\circ}-24.6^{\circ} \mathrm{N}\right.$ and $110^{\circ} \mathrm{W}$ ) aboard a boat with outboard motor (CICIMAR1), on 28th June 2014.

The zooplankton samples were collected with a conical net ( $60 \mathrm{~cm}$ mouth diameter, $250 \mathrm{~cm}$ long, $0.505 \mathrm{~mm}$ mesh) towed in an oblique trajectory at depths from $50 \mathrm{~m}$ to the surface in a circular path at 2.5 knots for 5 min during the day or night (Smith \& Richardson 1979). Complete samples of zooplankton were preserved in $80 \%$ ethanol. Tissue samples of $A$. thazard and $A$. rochei adults were obtained from sport fishing site in San Jose del Cabo, Baja California Sur on 5th July 2014. Adult specimens were identified with the taxonomic keys of Scombridae (Collette 2001). Such tissue samples were used to obtain reference sequences of Auxis spp.

Larvae were sorted from zooplankton samples, identified to the Auxis genus level (Moser 1996), and divided into 3 developmental stages: preflexion, flexion and postflexion, based on the degree of flexion of the terminal section of the notochord during formation of the caudal fin (Kendall et al. 1984).

\section{MoRPHOLOGICAL REVISION}

A total of 23 larvae were used in the revision of pigmentation patterns (number and position of pigment spots). Five measurements used by Rebollar-Prudente (2000) were recorded: notochord or standard length (NL), head length (HL), snout-to-anus length (PAL), horizontal eye diameter (ED), and upper jaw length (UJL) (Fig. 2), were measured for each larva in a stereomicroscope (Stemi SV6, Carl Zeiss ${ }^{\circledR}$, Oberkochen, Germany) with a calibrated micrometer.

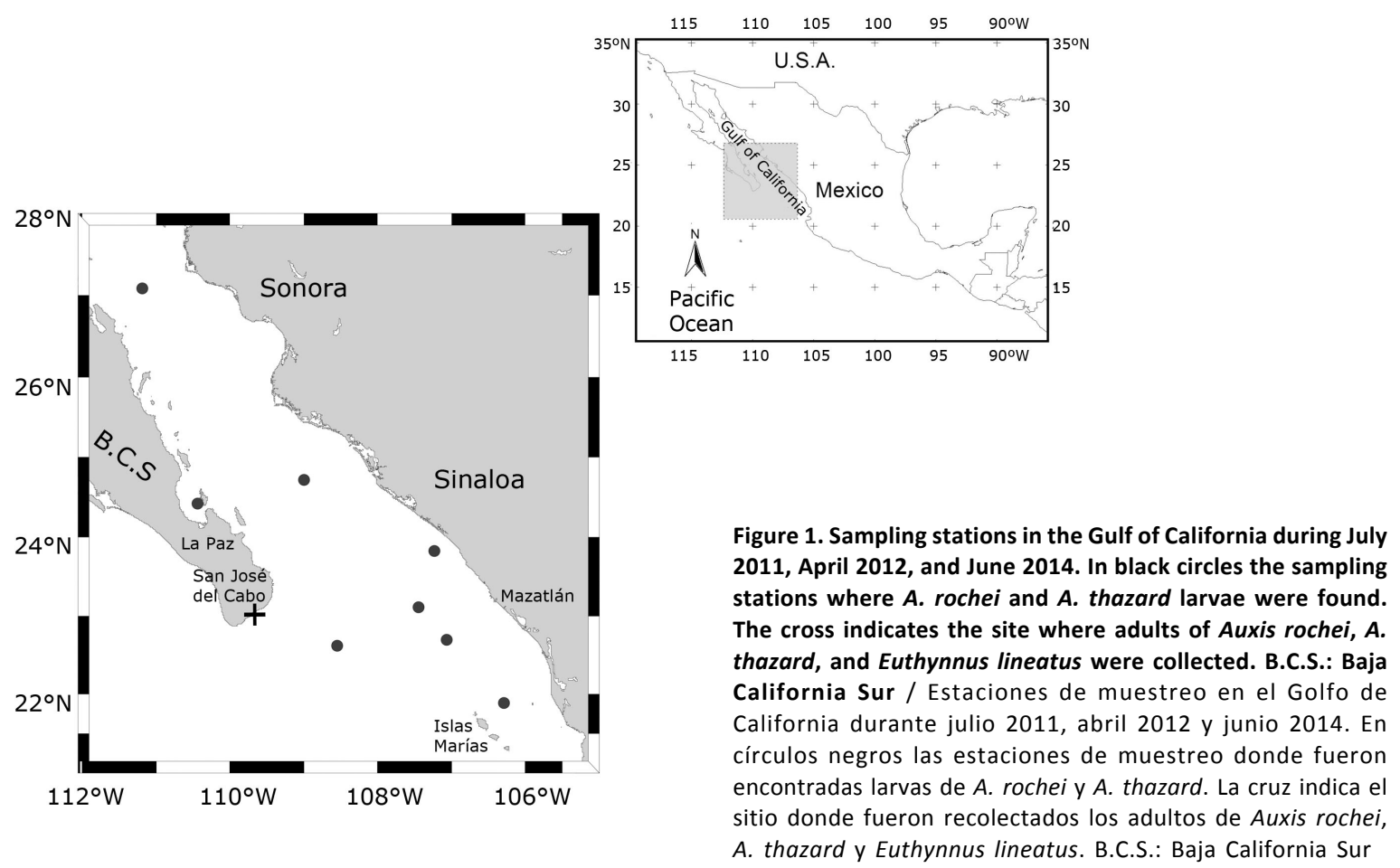

Vol. 53, N², 2018 


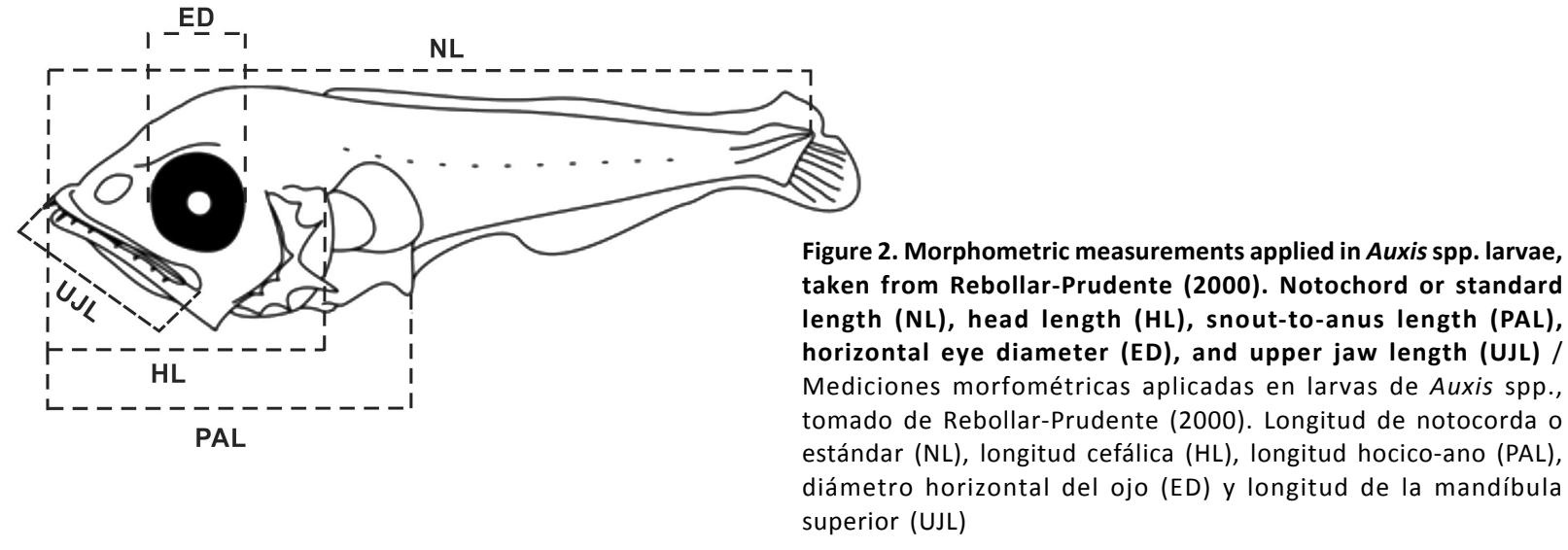

\section{MoleCUlar IDENTIFICATION OF AUXIS SPECIES}

Genomic DNA from adult tissue samples and larvae was extracted following a modified salt extraction technique of Lopera-Barrero et al. (2008) and a Chelex extraction technique (Hyde et al. 2005), respectively. DNA extractions were done from isolated tissues of 7 scombrid adults (Auxis rochei, $\mathrm{n}=4 ;$ A. thazard, $\mathrm{n}=2$ and Euthynnus lineatus, $\mathrm{n}=1$ ), and 23 putative larvae of Auxis spp. (5 in preflexion, 6 in flexion and 12 in postflexion). A $700 \mathrm{bp}$ fragment of the COI gene of mtDNA was amplified with primers VF1 (52-TCTCAACCAACCACAAAGACATTGG32) (Ivanova et al. 2006) and FishR1 (52TAGACTTCTGGGTGGCCAATCA-32) (Ward et al. 2005). DNA amplifications were performed by PCR (Bibby Scientific Ltd, Staffordshire, UK) under the following conditions: 2 min at $94^{\circ} \mathrm{C}, 35$ cycles of $1 \mathrm{~min}$ at $94^{\circ} \mathrm{C}, 1 \mathrm{~min}$ at $50^{\circ} \mathrm{C}, 1 \mathrm{~min}$ at $72^{\circ} \mathrm{C}$ and a final extension of $4 \mathrm{~min}$ at $72^{\circ} \mathrm{C}$. PCR products $\left(20 \mu 1,100 \mathrm{ng} \mu \mathrm{l}^{-1}\right)$ were purified and sequenced in sense and antisense directions in an automatic sequencer (ABI Prism 3730XL, Applied Biosystems, Carlsbad, CA) at Macrogen (Seoul, South Korea). Sense and antisense sequences were aligned using Clustal W, implemented in MEGA version 6.0 software (Tamura et al. 2013). The best sequences were deposited in the GenBank (Accession numbers: KX419574 KX419603). Five COI sequences of 4 Scombridae species from the GenBank were used as references (Accession numbers between parentheses): $A$. rochei (LN908924), $A$. thazard (LN908925), E. lineatus (GU440322 and LN908928), and Scomber japonicus (GU440513).

Genetic distances of Kimura's two-parameter model (Kimura 1980) among adults, larvae at different developmental stages, and reference sequences of COI were used to display phylogenetic relationships by Neighbor Joining (NJ) tree (5000 bootstraps) with MEGA version 6.0 software, using the sequence of $S$. japonicus as outgroup. The interspecific and intraspecific cutoff criterion were established in agreement to those proposed by Avise (2000) and Hebert et al. (2003), who suggested that interspecific genetic variation is higher than $2 \%$ and intraspecific is rarely greater than $2 \%$, most being less than $1 \%$.

\section{Results}

\section{Molecular IDENTIFiCATION (COI)}

The intra-specific genetic divergences in adults of Auxis rochei, A. thazard, and Euthynnus lineatus ranged from $0-0.8 \%$ (Table 1). The inter-specific genetic divergences among adults of $A$. rochei, $A$. thazard and E. lineatus ranged from $2.7-11.2 \%$. The sequences of 15 larvae (4 in preflexion, 3 in flexion, and 8 in postflexion), had genetic divergences ranging from $0-1.2 \%$ when were compared to sequences of Auxis rochei adults and higher than $3 \%$ when were compared to sequences of $A$. thazard (3.1$3.7 \%$ ) and $E$. lineatus adults (10.7-11.9\%). The sequences of 7 larvae ( 1 in preflexion, 3 in flexion, and 3 in postflexion) had genetic divergences ranging from $0-0.4 \%$ when they were compared to sequences of $A$. thazard adults and higher than $2 \%$ when were compared to sequences of $A$. rochei (2.7-4.0\%) and E. lineatus adults (9.7-10.5\%). The sequence of 1 larva in postflexion had genetic divergences from $0-0.2 \%$ when it was compared to sequences of $E$. lineatus adults and higher than $9 \%$ when it was compared to sequences of $A$. thazard $(9.7 \%)$ and $A$. rochei adults $(10.2-10.9 \%)$. 
Table 1. Minimum, maximum (between parentheses), and mean percentages values of genetic divergences of COI mtDNA fraction obtained with Kimura's two-parameter model, among Auxis species (A. rochei and A. thazard), Euthynnus lineatus, and Scomber japonicus. N: number of individuals / Porcentajes promedio, mínimo y máximo (entre paréntesis) de divergencia genética de la fracción COI de ADNmt, obtenidos con el modelo parámetro dos de Kimura, entre especies de Auxis (A. rochei y A. thazard), Euthynnus lineatus y Scomber japonicus. N: número de individuos

\begin{tabular}{|c|c|c|c|c|c|c|c|}
\hline & $\begin{array}{c}\text { Adults of } \\
\text { Auxis rochei }\end{array}$ & $\begin{array}{c}\text { Adults of } \\
\text { Auxis thazard } \\
\end{array}$ & $\begin{array}{c}\text { Adults of } \\
\text { Euthynnus lineatus }\end{array}$ & $\begin{array}{c}\text { Putative larvae of } \\
\text { Auxis rochei }\end{array}$ & $\begin{array}{l}\text { Putative larvae of } \\
\text { Auxis thazard }\end{array}$ & $\begin{array}{c}\text { Putative larva of } \\
\text { Euthynnus lineatus }\end{array}$ & $\begin{array}{c}\text { Adult of } \\
\text { Scomber japonicus }\end{array}$ \\
\hline & $\mathrm{N}=5$ & $\mathrm{~N}=3$ & $\mathrm{~N}=3$ & $\mathrm{~N}=15$ & $\mathrm{~N}=7$ & $\mathrm{~N}=1$ & $\mathrm{~N}=1$ \\
\hline $\begin{array}{l}\text { Adults of } \\
\text { Auxis rochei }\end{array}$ & $\begin{array}{c}(0-0.8) \\
0.5\end{array}$ & $\begin{array}{c}(2.7-3.5) \\
3.2\end{array}$ & $\begin{array}{c}(10.2-11.2) \\
10.8\end{array}$ & $\begin{array}{c}(0-1.2) \\
0.5\end{array}$ & $\begin{array}{c}(2.7-4.0) \\
3.2\end{array}$ & $\begin{array}{c}(10.2-10.9) \\
10.7\end{array}$ & $\begin{array}{c}(15.4-16.2) \\
15.9\end{array}$ \\
\hline $\begin{array}{l}\text { Adults of } \\
\text { Auxis thazard }\end{array}$ & & 0 & $\begin{array}{l}(9.7-10.0) \\
9.9\end{array}$ & $\begin{array}{c}(3.1-3.7) \\
3.5\end{array}$ & $\begin{array}{c}(0-0.4) \\
0.2\end{array}$ & $\begin{array}{l}(9.7-9.7) \\
9.7\end{array}$ & $\begin{array}{c}(15.7-15.7) \\
15.7\end{array}$ \\
\hline $\begin{array}{l}\text { Adults of } \\
\text { Euthynnus lineatus }\end{array}$ & & & $\begin{array}{c}(0.2-0.4) \\
0.3\end{array}$ & $\begin{array}{c}(10.7-11.9) \\
11.2\end{array}$ & $\begin{array}{c}(9.7-10.5) \\
10.0\end{array}$ & $\begin{array}{c}(0-0.2) \\
0.1\end{array}$ & $\begin{array}{c}(18.1-18.7) \\
18.4\end{array}$ \\
\hline $\begin{array}{l}\text { Putative larvae of } \\
\text { Auxis rochei }\end{array}$ & & & & $\begin{array}{c}(0-1.2) \\
0.5\end{array}$ & $\begin{array}{c}(3.1-4.2) \\
3.5\end{array}$ & $\begin{array}{c}(10.7-11.7) \\
11.1\end{array}$ & $\begin{array}{c}(15.7-16.5) \\
16.2\end{array}$ \\
\hline $\begin{array}{l}\text { Putative larvae of } \\
\text { Auxis thazard }\end{array}$ & & & & & $\begin{array}{c}(0-0.8) \\
0.3\end{array}$ & $\begin{array}{l}(9.7-10.2) \\
9.9\end{array}$ & $\begin{array}{c}(15.7-15.9) \\
15.8\end{array}$ \\
\hline $\begin{array}{l}\text { Putative larva of } \\
\text { Euthynnus lineatus }\end{array}$ & & & & & & -- & 18.4 \\
\hline $\begin{array}{l}\text { Adult of } \\
\text { Scomber japonicus }\end{array}$ & & & & & & & -- \\
\hline
\end{tabular}

--, No data because there was only one individual of that species

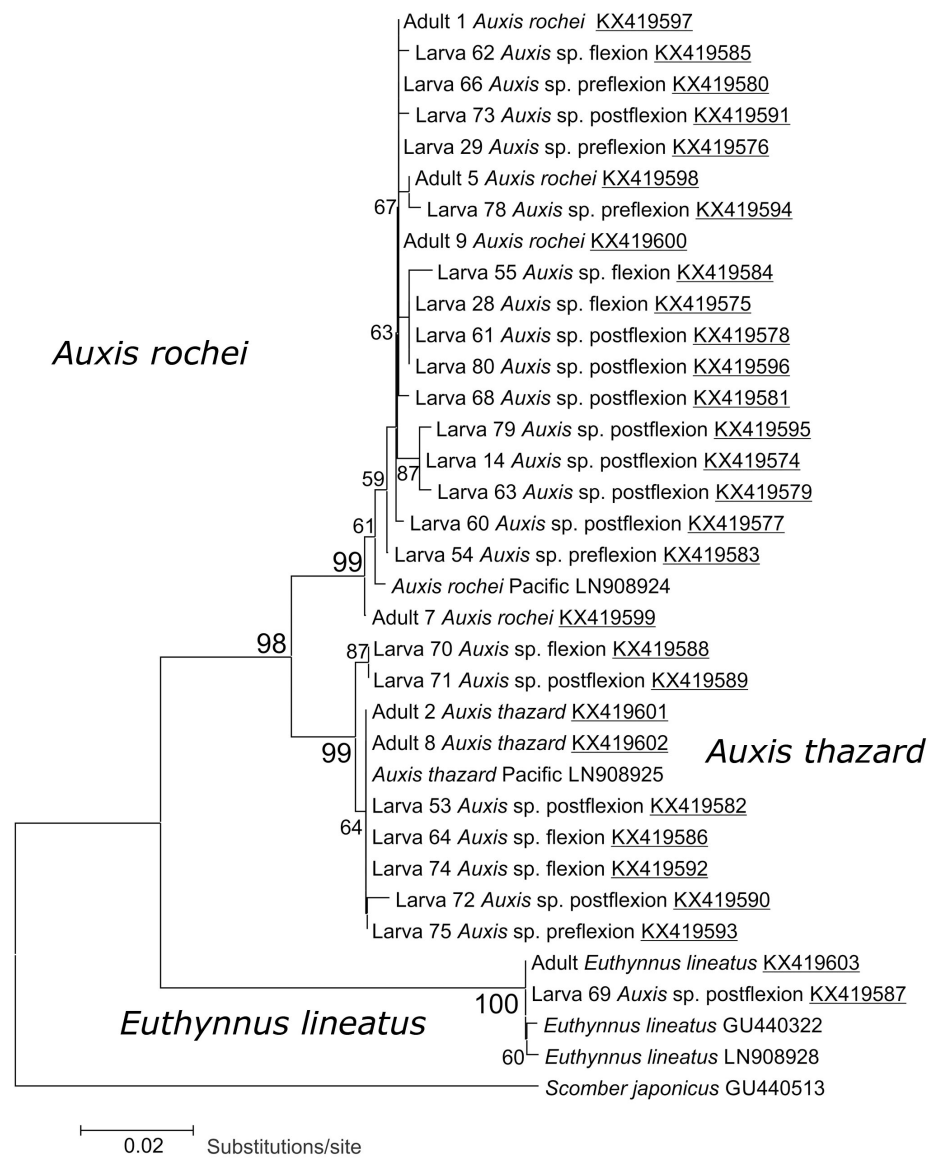

Figure 3. Neighbor-joining trees based on the partial sequences of $\mathrm{COI}(504 \mathrm{bp}$ ) gene of the mitochondrial DNA. Numbers beside the branches indicate bootstrap values $(>50 \%)$, based on 5,000 replicates. Accession numbers of new sequences (this study) are underlined. Scale bar represents the genetic distance of Kimura's two-parameter model / Árbol filogenético de unión del vecino más próximo basado en las secuencias parciales del gen $\mathrm{CO}$ (504 pb) del ADN mitocondrial. Los números a los lados de las ramas indican los valores de remuestreo $(>50 \%)$, basados en 5.000 réplicas. Los números de acceso de nuevas secuencias (este estudio) están subrayados. La barra de la escala representa la distancia genética del modelo parámetro dos de Kimura

Vol. 53, N², 2018 
The NJ tree showed that sequences from each species were confined to a single clade, supported by bootstrap confidence levels of 99-100\% (Fig. 3). Fifteen larvae were contained within $A$. rochei, 7 within $A$. thazard, and 1 within E. lineatus clades. These results statistically corroborate the identity of the 23 larvae of Scombridae collected at the entrance and southern Gulf of California.

\section{MORPHOLOGICAL DESCRIPTION}

The morphological characteristics for $A$. rochei and $A$. thazard larvae (15 and 7, respectively) were described based on the genetic identity of each species as defined above.

Pigmentation (Table 2, Figs. 4-7): from 1 to 4 pigment spots were observed on the tip of the lower jaw (TLJ) in both species; however, 2 larvae of $A$. rochei (preflexion and flexion stages) did not show this pigmentation. Several pigments spots were observed at the posterior cephalic dorsal region (PCDR) in almost all $A$. rochei and
A. thazard larvae, with 2 larvae of $A$. rochei (in preflexion and flexion) not showing such pigmentation. No pigment spots were observed in the anterior cephalic dorsal region (ACDR) of preflexion larvae and most of the flexion and postflexion larvae. From one to several pigment spots were observed in the ACDR of some flexion and postflexion larvae of both species. The biggest $A$. thazard (5.04 mm) and A. rochei (10.58 mm) larvae showed several pigment spots at ACDR. A pigment spot was observed at cleithral symphysis (CS) of all larvae of $A$. thazard and $A$. rochei, at all developmental stages, except in 2 larvae of A. rochei at preflexion.

Several pigment spots were observed dorsally on gut (DG) of both species at all developmental stages except in 2 larvae of $A$. rochei (preflexion and flexion). One pigment spot anterior to anus (AA) was observed in larvae of both species, at all developmental stages, except in 1 larva of $A$. thazard in postflexion. One larva of $A$. rochei in postflexion showed as much as 11 pigment spots AA.

Table 2. Pigment spot patterns of putative species of Auxis and Euthynnus larvae, after molecular identification with COI. Standard length (NL) in $\mathrm{mm}$, tip of lower jaw (TL), posterior cephalic dorsal (PCDR), and anterior cephalic dorsal (ACDR) regions, cleithral symphysis (CS), dorsal gut (DG), anterior to anus (AA), postanal ventral midline (PVM), dorsal caudal (DC), No data (--) / Patrones de pigmentación de especies putatitvas de larvas de Auxis y Euthynnus, después de la identificación molecular con COI. Longitud estándar (NL) en mm, punta de la mandíbula inferior (TLJ), regiones cefálicas posteriores dorsales (PCDR) y cefálicas anteriores dorsales (ACDR), sínfisis cleitral (CS), dorsal del estómago (DG), anterior al ano (AA), línea media ventral postanal (PVM), dorsal caudal (DC), Sin dato (--)

\begin{tabular}{lcccccccccc}
\hline \multirow{2}{*}{ Putative species } & Larval stage & NL & TLJ & PCDR & ACDR & CS & DG & AA & PVM & DC \\
& & & & & & & & & & \\
\hline \multirow{2}{*}{ Auxis rochei } & Preflexion & 3.50 & 0 & No & No & No & Yes & Yes & 15 & 1 \\
& Preflexion & 3.57 & 1 & Yes & No & No & No & Yes & 14 & 1 \\
& Preflexion & 3.58 & 2 & Yes & No & Yes & Yes & Yes & 10 & 2 \\
& Preflexion & -- & 1 & Yes & No & -- & Yes & -- & 11 & 0 \\
& Flexion & 3.61 & 1 & Yes & No & Yes & Yes & -- & 9 & 0 \\
& Flexion & 4.40 & 0 & No & No & Yes & Yes & -- & 9 & -- \\
& Flexion & -- & - & Yes & No & -- & No & -- & -- & 0 \\
& Postflexion & 4.82 & 3 & Yes & No & Yes & Yes & -- & 10 & 0 \\
& Postflexion & 5.00 & 1 & Yes & No & Yes & Yes & -- & 10 & 0 \\
& Postflexion & 5.05 & 3 & Yes & 1 & Yes & Yes & Yes & 11 & 0 \\
& Postflexion & 5.11 & 4 & Yes & No & Yes & Yes & Yes & 11 & 0 \\
& Postflexion & 5.50 & 1 & Yes & 1 & Yes & Yes & -- & 9 & 2 \\
& Postflexion & 5.60 & 1 & Yes & No & Yes & Yes & -- & 9 & 0 \\
& Postflexion & 5.73 & 2 & Yes & No & Yes & Yes & Yes & 17 & 1 \\
& Postflexion & 10.58 & 2 & Yes & Yes & Yes & Yes & -- & -- & -- \\
& Preflexion & 3.20 & 1 & Yes & No & Yes & Yes & -- & 7 & 0 \\
& Flexion & 3.60 & 1 & Yes & 1 & Yes & Yes & -- & 10 & 0 \\
& Flexion & 4.00 & 1 & Yes & No & Yes & Yes & -- & 11 & 0 \\
& Flexion & -- & 2 & Yes & No & Yes & Yes & -- & 7 & 0 \\
& Postflexion & 4.50 & 2 & Yes & No & Yes & Yes & No & 11 & 2 \\
& Postflexion & 4.70 & -- & Yes & 1 & Yes & Yes & -- & 10 & 2 \\
& Postflexion & 5.04 & -- & Yes & Yes & Yes & Yes & Yes & 14 & - \\
& Postflexion & 6.00 & 0 & Yes & Yes & Yes & Yes & No & 9 & 0 \\
\hline & & & & & & & & & &
\end{tabular}




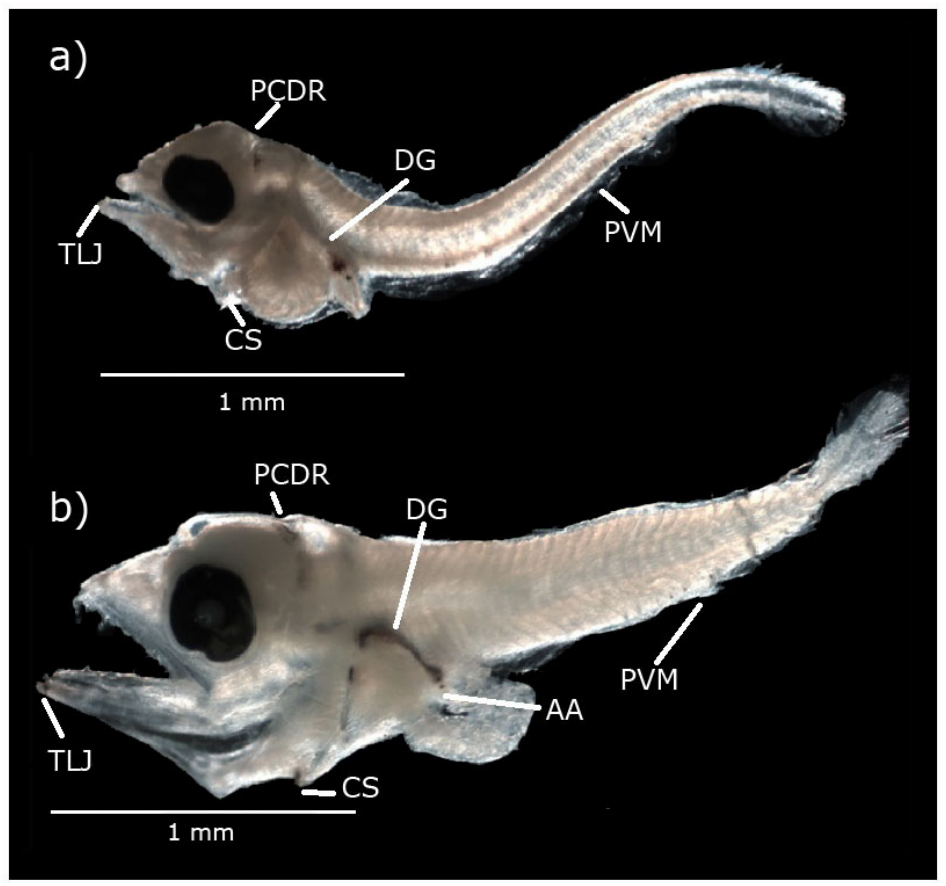

Figure 4. Some of the pigment spot patterns shared by Auxis thazard (a) and $A$. rochei (b) larvae in preflexion stage, at $3.2 \mathrm{~mm}$ and $3.58 \mathrm{~mm} \mathrm{NL}$, respectively. TL: tip of lower jaw, PCDR: posterior cephalic dorsal region, CS: cleithral symphysis, DG: dorsal gut, AA: anterior to anus, PVM: postanal ventral midline / Algunos de los patrones de pigmentación compartidos por larvas de Auxis thazard (a) y $A$. rochei (b) en estadio de preflexion, a los $3,2 \mathrm{~mm}$ y 3,58 $\mathrm{mm}$ NL respectivamente. TLJ: punta de la mandíbula inferior, PCDR: región cefálica posterior dorsal, CS: sínfisis cleitral, DG: dorsal del estómago, AA: anterior al ano, $P V M$ : línea media ventral postanal

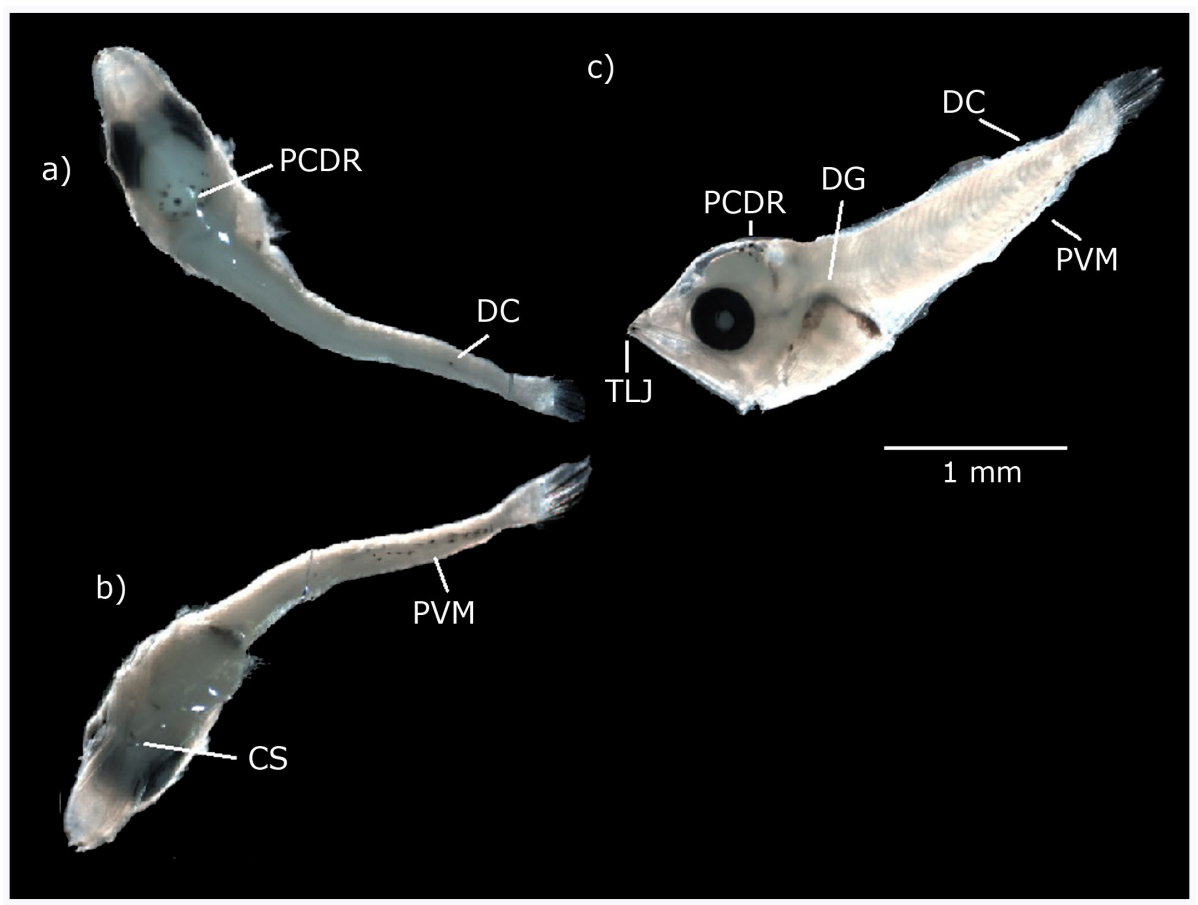

Figure 5. Pigment spot patterns of Auxis rochei flexion larvae at $3.61 \mathrm{~mm} \mathrm{NL}$. a) dorsal view; b) ventral view; c) lateral view. TLJ: tip of lower jaw, PCDR: posterior cephalic dorsal region, CS: cleithral symphysis, DG: dorsal gut, PVM: postanal ventral midline, DC: dorsal caudal / Patrones de pigmentación de larva de Auxis rochei en estadio de flexión a los 3,61 mm NL. a) vista dorsal; b) vista ventral; c) vista lateral. TLJ: punta de la mandíbula inferior, PCDR: región cefálica posterior dorsal, CS: sínfisis cleitral, DG: dorsal del estómago, PVM: línea media ventral postanal, DC: dorsal caudal 


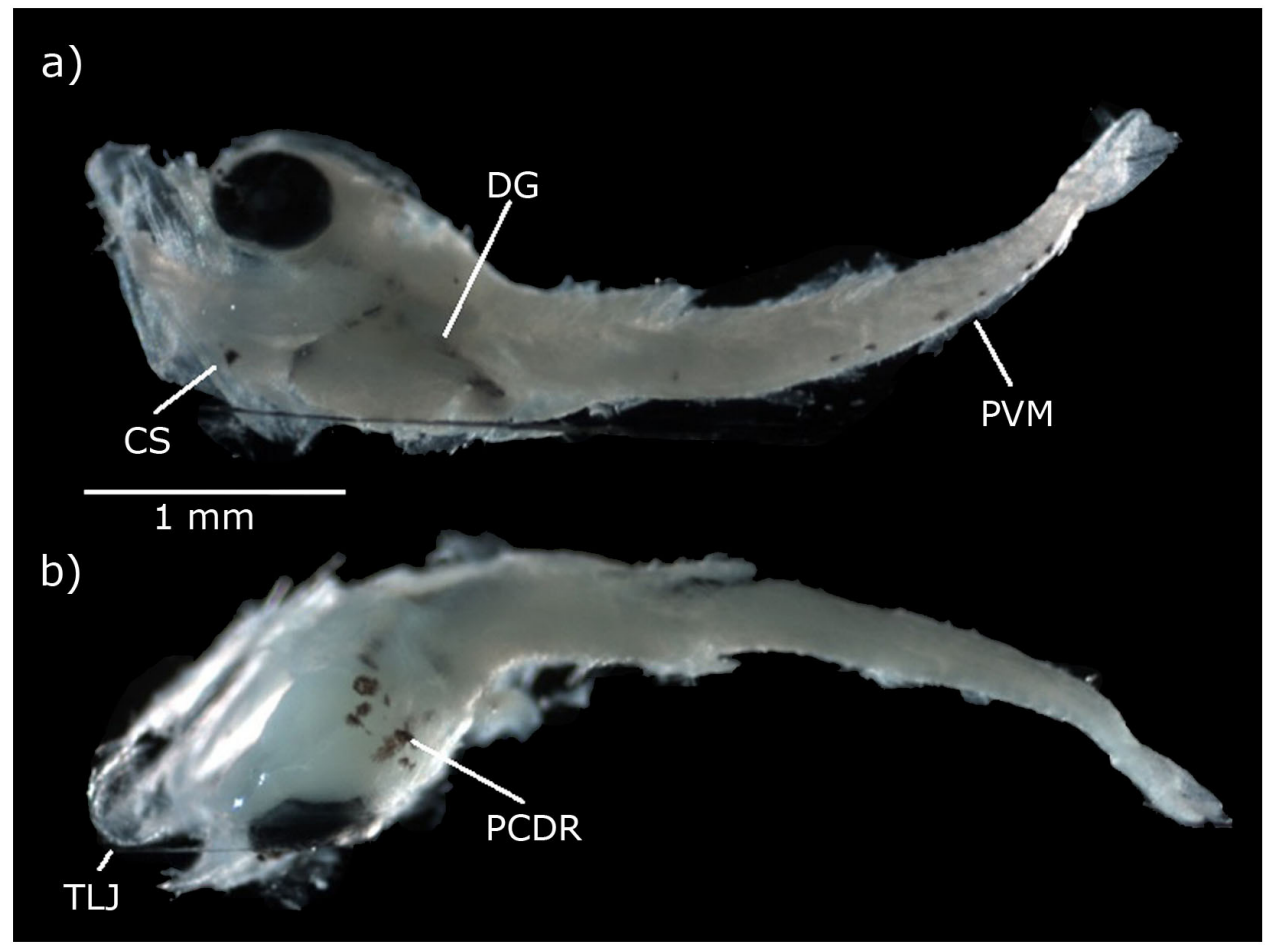

Figure 6. Pigment spot patterns of Auxis thazard flexion larvae at $4.00 \mathrm{~mm}$ NL. a) ventral view; b) dorsal view. TL: tip of lower jaw, PCDR: posterior cephalic dorsal region, CS: cleithral symphysis, DG: dorsal gut, PVM: postanal ventral midline, DC: dorsal caudal / Patrones de pigmentación de larva de Auxis thazard en estadio de flexión a los 4,00 $\mathrm{mm} \mathrm{NL}$. a) vista ventral; b) vista dorsal. TLJ: punta de la mandíbula inferior, PCDR: región cefálica posterior dorsal, CS: sínfisis cleitral, DG: dorsal del estómago, PVM: línea media ventral postanal

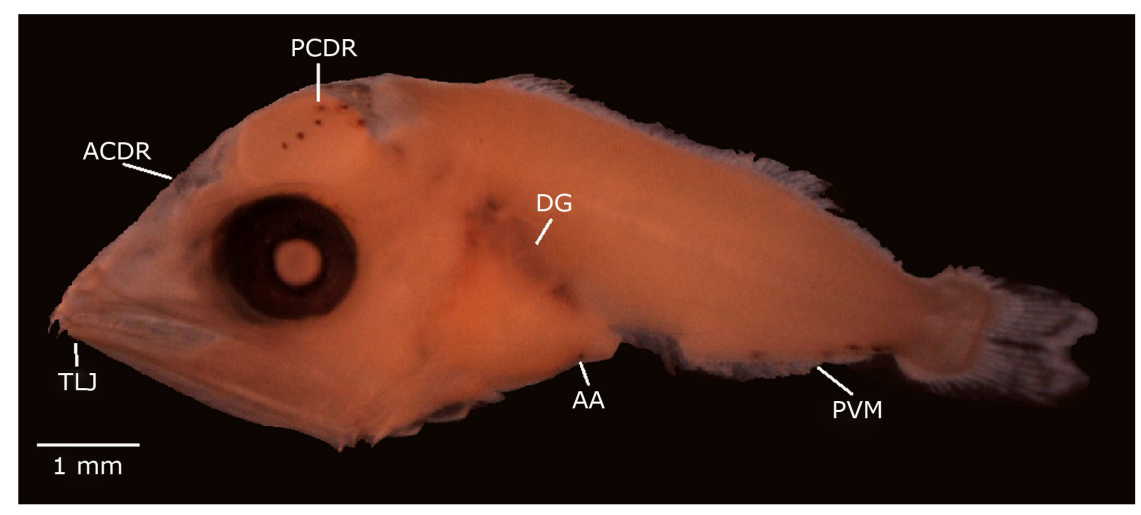

Figure 7. Pigment spot patterns of Auxis rochei postflexion larvae at $10.58 \mathrm{~mm}$ NL. Patterns start to fade due epidermis tissue thickening. TL: tip of lower jaw, PCDR: posterior cephalic dorsal region, ACDR: anterior cephalic dorsal region, DG: dorsal gut, AA: anterior to anus, PVM: postanal ventral midline / Patrones de pigmentación de larva de Auxis rochei en estadio de postflexión a los 10,58 mm NL. Los patrones comienzan a desvanecerse debido al engrosamiento de la epidermis. TLJ: punta de la mandíbula inferior, PCDR: región cefálica posterior dorsal, ACDR: región cefálica anterior dorsal, DG: dorsal del estómago, AA: anterior al ano, PVM: línea media ventral postanal 
A higher variation was observed in the number of pigment spots on the postanal ventral midline (PVM). In larvae of $A$. rochei such pigment spots ranged from 10-15 in preflexion, 9 in flexion, and 9-17 in postflexion. Larvae of $A$. thazard showed 7 pigment spots in a preflexion larva, from 7-11 in flexion, and 10-14 in postflexion. Dorsally in caudal peduncle (DC), from 0-2 pigment spots were observed in both species at all developmental stages.

Morphometry: A lower number of larvae at different developmental stages were used in morphometric analysis (body and head measurements), because several larvae were degraded or deformed (twisted or bent) by the ethanol dehydration. Thus, measurements were obtained of the best-preserved larvae genetically identified: 5 larvae of $A$. rochei ( 1 in preflexion and 4 in postflexion) and 4 larvae of $A$. thazard ( 1 in preflexion, 2 in flexion, and 1 in postflexion). Ratio of PAL/NL was lower in preflexion larva of $A$. rochei (0.31), in comparison to preflexion larva of $A$. thazard (0.44), but it was similar in postflexion larvae of both species. Ratio of HL/NL was similar in both species at preflexion and postflexion stages. Ratio of UJL/HL was higher in preflexion larva of $A$. rochei $(0.89)$ in comparison to preflexion larva of $A$. thazard (0.66), but it was similar in both species at postflexion stage. Finally, ratio of ED/ HL was similar in both species at postflexion stage (Table 3).

\section{Discussion}

Molecular analysis with COI of the mtDNA demonstrated the existence of $A$. thazard and $A$. rochei larvae in the Gulf of California. To a large extent, our results were in agreement with those cutoff criterion established by Avise (2000) and Hebert et al. (2003), because some larvae of Auxis rochei showed intraspecific divergences higher than $1 \%$ when compared to adults of the same species. Such intraspecific variation could be the natural variation in species, because larvae and adults of $A$. rochei were in the same clade in the NJ tree, with a high statistical support (99\%). Previous studies, with COI fraction of mtDNA in larvae or juveniles of Auxis genera, have found statistical support higher than $97 \%$ of bootstrap to discriminate species of Auxis (Chow et al. 2003, Ji et al. 2011, Kumar et al. 2013). In addition, in the Gulf of California were confirmed the same 8 variable sites that were found to discriminate between Auxis rochei and A. thazard from the Mediterranean Sea (Puncher et al. 2015).

In this study, such as Azmir et al. (2017), DNA barcoding was a better method for deeper taxonomic levels identification and was able to validate the accuracy of traditional larval fish identification. However, as mentioned Azmir et al. (2017), the success of using barcoding for species identification strongly depends on the presence of high-quality reference sequences. In our

Table 3. Minimum, maximum (between parentheses), and mean values, of body ratios of Auxis rochei and A. thazard larvae. Standard length (NL), preanal length (PAL), head length (HL), upper jaw length (UJL), horizontal eye diameter (ED), and number of larvae (N) / Valores promedio, mínimo y máximo (entre paréntesis), de proporciones corporales de larvas de Auxis rochei y A. thazard. Longitud estándar (NL), longitud preanal (PAL), longitud cefálica (HL), longitud de la mandíbula superior (UJL), diámetro horizontal del ojo (ED), y número de larvas (N)

\begin{tabular}{|c|c|c|c|c|c|c|}
\hline \multirow{3}{*}{ Body ratio } & \multicolumn{2}{|c|}{ Auxis rochei } & \multicolumn{3}{|c|}{ Auxis thazard } & \multirow{2}{*}{$\begin{array}{c}\text { Euthynnus lineatus } \\
\text { Postflexion }\end{array}$} \\
\hline & Preflexion & Postflexion & Preflexion & Flexion & Postflexion & \\
\hline & $\mathrm{N}=1$ & $\mathrm{~N}=4$ & $\mathrm{~N}=1$ & $\mathrm{~N}=2$ & $\mathrm{~N}=1$ & $\mathrm{~N}=1$ \\
\hline $\mathrm{PAL} / \mathrm{NL}$ & 0.31 & $\begin{array}{c}(0.40-0.47) \\
0.43\end{array}$ & 0.44 & $\begin{array}{c}(0.37-0.39) \\
0.38\end{array}$ & 0.42 & 0.53 \\
\hline $\mathrm{HL} / \mathrm{NL}$ & 0.26 & $\begin{array}{c}(0.26-0.33) \\
0.28\end{array}$ & 0.28 & $\begin{array}{c}(0.25-0.25) \\
0.25\end{array}$ & 0.30 & 0.33 \\
\hline UJL/HL & 0.89 & $\begin{array}{c}(0.55-0.80) \\
0.70\end{array}$ & 0.66 & $\begin{array}{c}(0.67-0.80) \\
0.73\end{array}$ & 0.71 & 0.80 \\
\hline $\mathrm{ED} / \mathrm{HL}$ & -- & $\begin{array}{c}(0.28-0.38) \\
0.33\end{array}$ & 0.44 & $\begin{array}{c}(0.40-0.44) \\
0.42\end{array}$ & 0.36 & 0.35 \\
\hline
\end{tabular}

--, No data 
study, such reference sequences were obtained from adults specimens well identified and GenBank database.

Matsumoto (1959) suggested that the localities where Auxis larvae of about $3 \mathrm{~mm}$ occur probably represent actual spawning sites. The molecular identification of early Auxis larvae suggests the presence of spawning sites of both species in the Gulf of California during spring and summer. However, because sampling was not carried out throughout the year, results of spawning season were not conclusive. In other study, a combine data from DNA barcoding, comparative morphology and analysis of color pattern, link a serranid fish larvae to its adult, suggesting connectivity in this species across the Caribbean Sea (Baldwin \& Johnson 2014).

Since the late 50's there are antecedents which report difficulties in classification of tuna larvae, particularly of small tuna larvae of Auxis genera worldwide (Jones 1949, 1960; Uchida 1963, 1981). Moser (1996) proposed that to improve classification of such larvae a combination of methods, such as the number of myomeres, the body shape, head spination, and melanophores distribution, are required. In this study, molecular identification, pigment spot patterns, and morphometric were included.

Nevertheless, the pigmentation did not show clear patterns that could help to differentiate between $A$. thazard and $A$. rochei larvae. One or 2 pigment spots could be present at the tip of the snout in both species of Auxis genera. Further, such characteristic is present in other genera of Scombridae, like Katsuwonus and Thunnus (Richards 2006), and appears in larvae from the flexion stage (Jones 1960). In the case of Euthynnus lineatus larva, 3 pigment spots were observed on the left side of the lower jaw, not at the tip. The pigment spots at the anterior cephalic dorsal region could be present in flexion and postflexion larvae of $A$. thazard and A. rochei, respectively, and were even present in postflexion larva of E. lineatus. These pigment spots were recorded by Uchida (1963), who reported the appearance of the first anterior pigment in larvae of $8 \mathrm{~mm}$ of length. In this study, the first pigment spot in the anterior cephalic region was recorded in a flexion larva of $A$. thazard $(3.6 \mathrm{~mm}$ of standard length) and a postflexion larva of $A$. rochei $(5.05 \mathrm{~mm}$ of standard length). The pigment spot at cleithral symphysis was present in both species. This characteristic has been recorded in larvae of Auxis, but this is also present in larvae of Euthynnus (Jones 1949, 1960; Uchida 1963, 1981).

The pigment spots dorsally on gut were present in most larvae of both species and the number and the size of such pigments seems to be random. The pigment spot anterior to anus was present in some larvae of both species. In the study of Rebollar-Prudente (2000), such pigment spots were useful to separate larvae of Auxis genera, but in the present study did not support differentiation between both species.

The pigment spots on postanal ventral midline showed some differences in number between preflexion larvae of A. rochei and a larva of $A$. thazard. However, such pigment spots in flexion and postflexion larvae were uninformative for differentiation between the 2 species. Even the $E$. lineatus larva showed similar numbers in pigment spots on postanal ventral midline, but such pigment spots were paired, while in Auxis larvae those were unpaired. The pigment spots dorsally on caudal peduncle were also uninformative, because they were present only in some larvae of both species.

Thus, the pigment spots at the tip of the snout, cephalic, cleithral symphysis, anterior to anus, postanal ventral midline (in flexion and postflexion), and dorsally on caudal peduncle were uninformative for separating larvae of Auxis genera, because they were present only in some larvae of both species, and did not show clear patterns of differentiation. Almost all those pigment spots were shared with the E. lineatus larva. There were some differences in the number of pigment spots on postanal ventral midline between preflexion larvae of $A$. rochei and a larva of $A$. thazard. However, because there was only 1 larva of $A$. thazard in preflexion, such differences should be corroborated in a large number of larvae.

There is a group of pigment spots that were used by previous studies to classify 2 larval types of Auxis (Matsumoto 1959, Uchida 1981). Larvae of type I ( $A$. thazard) showed 2 or more lines of pigment spots in the caudal peduncle (dorsal, ventral, and lateral) and larvae of type II (A. rochei) only showed 1 or 2 lines of pigment spots in the caudal peduncle (dorsal and ventral). Richards (2006) employed this classification, but such classification did not separate larvae in preflexion and flexion stages, because the greatest changes happen after the $7 \mathrm{~mm}$ of larval length (Matsumoto 1959, Uchida 1981, Richards 2006). Ji et al. (2011) reviewed the differences in pigment spot patterns of caudal peduncle and found that only some larvae of Auxis rochei showed the dorsal line of pigment spots. In the present study, most larvae of both Auxis species did not show the dorsal line of pigment spots, probably because almost all larvae were smaller than $7 \mathrm{~mm}$. 
Morphometrics showed some differences in PAL/NL and $\mathrm{UJL} / \mathrm{HL}$ ratios between preflexion larvae of $A$. thazard and $A$. rochei. However, because only 1 larva each in preflexion was available for both species, such ratios should be confirmed in large sample sizes. The rest of the body ratios were uninformative for differentiating between A. thazard and A. rochei larvae. Rebollar-Prudente (2000) used morphometric and meristic to classify 2 larval types of Auxis. He employed a discriminant analysis to separate preflexion larvae of the 2 types and developed classification functions using the measures of standard length, eye diameter, head depth, and snout length. In the present study, similar to that of Rebollar-Prudente, the preanal, upper jaw and standard length were informative to differentiate preflexion larvae of $A$. thazard and $A$. rochei.

As in the present study, Chow et al. (2003) also highlighted the division of Auxis species with COI fraction in the west Pacific, but they were not able to relate it to morphologic characteristics of larvae. They concluded that could be separated using gill rakers, however such characteristic could be useful in more developed larvae or juveniles.

In conclusion, this study rejects the taxonomic hypothesis of morphological differentiation of Auxis spp. larvae and confirms the constraints to identifying larvae in preflexion, flexion, and postflexion of Auxis spp, using pigmentation patterns and morphometric, as proposed early by Jones $(1949,1960)$ and Uchida $(1963,1981)$. Even though there are some differences in the pigment spots on postanal ventral midline and PAL/NL and UJL/HL ratios of preflexion larvae of Auxis spp., such characteristics are not conclusive. At the moment, to identify larvae of Auxis collected in the Gulf of California, we suggest the use of molecular identification with COI fraction of mtDNA or morphological identification should be more conservative and use Auxis spp. This finding by no means try to undermine the work of taxonomists, because DNA barcoding rely on sequences obtained from voucher specimens well identified through their morphology or curated in the case of misidentifications (Hubert et al. 2015, Azmir et al. 2017, Collet et al. 2017). Hence, the taxonomic studies of larval fish should continue using combination of both conventional (morphology) and new (DNA barcode) methods (Azmir et al. 2017). In future ecologic studies, molecular identification will help to identify spawning sites of both Auxis species, increasing our understanding of spawning habitat selection as well as the interactions of both species.

\section{ACKNOWLEDGEMENTS}

This work is dedicated to the late Alejandro ZárateVillafranco who assisted with Auxis larvae separation, morphometric, pigmentation description, and taking photos. María del Rocio Pacheco Chávez of CICIMARIPN supported taking photos. MEXBOL provided financial support to assist at the $39^{\text {th }}$ Annual Larval Fish Conference. N.D.V., L.S.V., and S.P.A.J.R. are fellows of EDI-IPN. L.S.V. and S.P.A.J.R. are fellows of COFAA-IPN. M.J.O.M. was a recipient of a BEIFI-IPN and a CONACYT fellowship (No. 308039). Funding was provided by IPNSIP grants 1885 and 20180339, and SEP-CONACYT grant 2014-236864 and Fronteras de la Ciencia-CONACyT grant 2015-2-280.

\section{LITERATURE CITED}

Apango-Figueroa EA, L Sánchez-Velasco, MF LavínPeregrina, VM Godínez-Sandoval \& ED Barton. 2015. Larval fish habitats in a mesoscale dipole eddy in the Gulf of California. Deep-Sea Research Part I 103: 1-12.

Avendaño-Ibarra R, E Godínez-Domínguez, G AcevesMedina, E González-Rodríguez \& A Trasviña. 2013. Fish larvae response to biophysical changes in the Gulf of California, Mexico (winter-summer). Journal of Marine Biology 2013: 1-17. <doi: 10.1155/2013/176760>

Avise JC. 2000. Phylogeography: The history and formation of species, 464 pp. Harvard University Press, Cambridge.

Ayala E. 1998. Distribución espacio-temporal de las larvas de atunes en el Golfo de Tehuantepec, México. Universidad Autónoma Metropolitana, Unidad Iztapalapa. Informe Final del Proyecto G033, Mexico, D.F. <http:// www.conabio.gob.mx/institucion/proyectos/resultados/ InfG033.pdf>

Azmir IA, Y Esa, SMN Amin, IS Yasin Md \& FZ Yusof Md. 2017. Identification of larval fish in mangrove areas of Peninsular Malaysia using morphology and DNA barcoding methods. Journal of Applied Ichthyology 33: 998-1006. $<$ doi: 10.1111/jai.13425>

Baldwin CC \& GD Johnson. 2014. Connectivity across the Caribbean Sea: DNA barcoding and morphology unite an enigmatic fish larva from the Florida Straits with a new species of Sea Bass from Deep Reefs off Curaçao. PLoS ONE 9(5): e97661.<doi:10.1371/journal.pone.0097661>

Chow S, K Nohara, T Tanabe, T Itoh, S Tsuji, Y Nishikawa \& K Uchikawa. 2003. Genetic and morphological identification of larval and small juvenile tunas (Pisces: Scombridae) caught by a mid-water trawl in the western Pacific. Bulletin Fisheries Research Agency 8: 1-14. 
Collet A, JD Durand, E Desmarais, F Cerqueira, T Cantinelli, P Valade \& D Ponton. 2017. DNA barcoding post-larvae can improve the knowledge about fish biodiversity: an example from La Reunion, SW Indian Ocean. Mitochondrial DNA Part A. 29(6): 905-918. < doi: 10.1080/ 24701394.2017.1383406>

Collette BB. 2001. FAO species identification guide for fishery purposes. In: Carpenter KE \& VH Niem (eds). The living marine resources of the Western Pacific, Bony fishes 6: 3721-3726. FAO, Rome.

García A, F Alemany \& JM Rodríguez. 2002. Distribution of tuna larva off the Balearic Sea: Preliminary results of the Tunibal 0600 Larval Survey. Collective Volume of Scientific Papers ICCAT 54(2): 554-560.

Hebert PDN, S Ratnasingham \& JR deWaard 2003. Barcoding animal life: cytochrome oxidase subunit 1 divergences among closely related species. Proceedings of the Royal Society B: Biological Sciences 270: 596-599.

Hubert N, B Espiau, C Meyer \& S Planes. 2015. Identifying the ichthyoplankton of a coral reef using DNA barcodes. Molecular Ecology Resources 15: 57-67.

Hyde JR, E Lynn, R Humphreys, M Musyl, AP West \& R Vetter. 2005. Shipboard identification of fish eggs and larvae by multiplex PCR, and description of fertilized eggs of blue marlin, shortbill spearfish, and wahoo. Marine Ecology Progress Series 286: 269-277.

Ivanova NV, JR Dewaard \& PDN Hebert. 2006. An inexpensive, automationfriendly protocol for recovering highquality DNA. Molecular Ecology Notes 6: 998-1002. $<$ doi:10.1111/j.1471-8286.2006.01428.x>

Ji HS, JT Yoo, JH Ryu \& JK Kim. 2011. Molecular identification and morphological development of Auxis (Scombridae) larvae. Korean Journal of Fisheries and Aquatic Sciences 44(6): 677-683.

Jones S. 1949. Notes on the Frigate Mackerels, Auxis thazard (Lacepède) and A. tapeinosoma Bleeker, From Indian Waters. International Journal of Fisheries and Aquaculture 5(1): 189-194.

Jones S. 1960. Notes on eggs, larvae and juveniles of fishes from Indian Waters. VI. The genus Auxis Cuvier, VII. Sarda orientalis (Temminck and Schlegel). Indian Journal of Fisheries 7(2): 337-347.

Joshi KK, EM Abdussamad, KP Saidkoya, P Rohit, S Ghosh, KR Sreenath, M Beni, KK Bineesh \& KV Akhilesh. 2012. Taxonomy and key for the identification of tuna species exploited from the Indian EEZ. Indian Journal of Fisheries 59(3): 53-60.

Kendall AW, EH Ahlstrom \& HG Moser. 1984. Early life history stages of fishes and their characters. In: Moser HG, WJ Richards, DM Cohen, MP Fahay, AW Kendall Jr \& SL Richardson (eds). Ontogeny of the immune system of fish. American Society of Ichthyologists and Herpetologists, Special Publication 1: 11-22. Allen Press, Lawrence.
Kimura DK. 1980. Likelihood methods for the von Bertalanffy growth curve. Fishery Bulletin 77(4): 765-776.

Ko HL, YT Wang, TS Chiu, MA Lee, MY Leu, KZ Chang \& KT Shao. 2013. Evaluating the accuracy of morphological identification of larval fishes by applying DNA barcoding. PLoS One 8(1): e53451.<doi:10.1371/journal.pone.0053451>

Kumar G, SP Kunal \& SK Shyama. 2013. Evolutionary history and phylogenetic relationship between Auxis thazard and Auxis rochei inferred from COI sequences of mtDNA. International Journal of Bioinformatics Research and Applications 9(6): 604. < doi: 10.1504/IJBRA.2013.056655>

Leis JM. 2015. Taxonomy and systematics of larval IndoPacific fishes: a review of progress since 1981. Ichthyological Research 62: 9-28.

Lopera-Barrero NM, JA Povh, RP Ribeiro, PC Gomes, CB Jacometo \& TD Silva-Lopes. 2008. Comparación de protocolos de extracción de ADN con muestras de aleta y larva de peces: extracción modificada con cloruro de sodio. Ciencia e Investigación Agraria 35(1): 77-86. < doi: 10.4067/ S0718-16202008000100008>

Majkowski J. 2007. Global fishery resources of tuna and tunalike species. FAO Fisheries Technical Paper 483: 1-54.

Matsumoto WM. 1959. Descriptions of Euthynnus and Auxis larvae from the Pacific and Atlantic Oceans and adjacent seas. The Carlsberg Foundation's oceanographical expedition round the World 1928-30 and previous DanaExpeditions. Dana-Report 50: 1-34. Høst \& Søn, Copenhagen.

Moser HG. 1996. The early stages of fishes in the California current region. CalCOFI Atlas 33: 1-1505.

Mudumala VK, VS Somvanshi \& WS Lakra. 2011. Phylogenetic relationships of coastal tunas inferred from mitochondrial DNA sequences in the cytochrome $c$ oxidase I (COI) gene - a study on DNA barcoding. Working Party on Neritic Tunas (WPNT) Indian Ocean Tuna Commission, IOTC-2011-WPNT01-12: 1-14. <http://iotc.org/sites/ default/files/documents/proceedings/2011/wpnt/IOTC2011-WPNT01-12.pdf>

Paine MA, JR McDowell \& JE Graves. 2007. Specific identification of western Atlantic Ocean scombrids using mitochondrial DNA cytochrome $c$ oxidase subunit I (COI) gene region sequences. Bulletin of Marine Science 80(2): 353-367.

Paine MA, JR McDowell \& JE Graves. 2008. Specific identification using COI sequence analysis of scombrid larvae collected off the Kona coast of Hawaii Island. Ichthyological Research 55(1): 7-16. < doi: 10.1007/s10228007-0003-4>

Pappalardo AM, A Cuttitta, A Sardella, M Musco, T Maggio, B Patti, S Mazzola \& V Ferrito. 2015. DNA barcoding and COI sequence variation in Mediterranean lantern fishes larvae. Hydrobiologia 749: 155-167. 
Puncher GN, H Arrizabalaga, F Alemany, A Cariani, IK Oray, FS Karakulak, G Basilone, A Cuttitta, S Mazzola \& F Tinti. 2015. Molecular identification of Atlantic Bluefin Tuna (Thunnus thynnus, Scombridae) larvae and development of a DNA character-based identification key for Mediterranean Scombrids. PLoS ONE 10(7): e0130407. $<$ doi:10.1371/journal. pone.0130407>

Rebollar-Prudente R. 2000. Diferenciación larval de las especies del género Auxis y la variación espaciotemporal de las concentraciones larvales de tres especies de la familia Scombridae en el Golfo de California, México. M.Sc. Tesis, Departamento de Plancton y Ecología Marina, Centro Interdisciplinario de Ciencias del Mar, La Paz, 63 pp.

Richards WJ. 2006. Early stages of Atlantic fishes: an identification guide for the western central North Atlantic, 2460 pp. Taylor \& Francis, Boca Raton.

Robertson MD, JR Ovenden \& SC Barker. 2007. Identification of small juvenile scombrids from northwest tropical Australia using mitochondrial DNA cytochrome $b$ sequences. Ichthyological Research 54(3): 246-252. < doi: 10.1007/s10228-007-0397-z>

Sánchez-Velasco L, MF Lavín-Peregrina, SPA JiménezRosenberg, VM Godínez-Sandoval, EM SantamaríaDel Ángel \& DU Hernández-Becerril. 2013. Threedimensional distribution of fish larvae in a cyclonic eddy in the Gulf of California during the summer. Deep-Sea Research Part I 75: 39-51.
Smith PE \& SL Richardson. 1979. Técnicas modelo para prospecciones de huevos y larvas de peces pelágicos. FAO Documentos Técnico de Pesca 175: 1-107.

Tamura K, G Stecher, D Peterson, A Filipski \& S Kumar. 2013. MEGA6: Molecular evolutionary genetics analysis version 6.0. Molecular Biology and Evolution 30: 2725 2729.

Uchida RN. 1963. Synopsis of biological data on frigate mackerel Auxis thazard (Lecépède) 1802 (Pacific Ocean). FAO Fisheries Biology Synopsis 51(8): 1-29.

Uchida RN. 1981. Synopsis of biological data on frigate tune, Auxis thazard, and bullet tuna, A. rochei. NOAA Technical Report NMFS Circular 4(124): 1-63.

Valdez-Moreno M, L Vásquez-Yeomans, M ElíasGutiérrez, NV Ivanova \& PDN Herbert. 2010. Using DNA barcodes to connect adults and early life stages of marine fishes from the Yucatan Peninsula, Mexico: potential in fisheries management. Marine and Freshwater Research 61: 665-671.

Ward RD, TS Zemlak, BH Innes, PR Last \& PDN Hebert. 2005. DNA barcoding Australia's fish species. Philosophical Transactions of the Royal Society of London, Series B: Biological Sciences 360: 1847-1857.

Received 11 April 2017 and accepted 31 May 2018

Editor: Claudia Bustos D. 